\title{
Assessment of Contamination by Petroleum Hydrocarbons in Sediments along Discharge Basin of Suez Oil Refinery Company, Southwest of the Suez Gulf
}

\author{
N. A. Farid, S. A. Mahmoud and O. E. Ahmed* \\ Egyptian Petroleum Research Institute, Nasr City, Cairo, \\ Egypt.
}

\begin{abstract}
THE PRESENT study was performed in discharge basin of Suez Oil Petroleum Company (SOPC), which is located southwest of the Suez Gulf. Sediment samples were collected from this area and investigated in 2012 - 2013 by Gas chromatography, Ultraviolet, and FT-IR spectroscopy. Gas chromatography analysis revealed petrogenic pollution and traces of biogenic hydrocarbons could also be detected. The concentration of total alkanes and unresolved complex mixture (UCM) in sediment samples ranged from 1116.3 up to $2137.4 \mu \mathrm{g} / \mathrm{g}$ with average $1638.683 \mu \mathrm{g} / \mathrm{g}$. dry weights, the discharge of hazardous materials such as petroleum and chemical solvents to the aquatic environment has become the focus of increasing regulatory and public concern because of the adverse impacts of such materials on human health and the environment; Petroleum concentrations as low as $0.1 \mathrm{ppm}$ have been shown to be acutely toxic. As the concentration was greater than the natural background concentration; therefore, the region can be considered (highly) polluted. Despite the high concentration of anthropogenic contaminates including industries, processing activities and other non-point source pollution. The unusual results may be related to wastes of conversion operations of crude oil to refined products. The present work demonstrates the complexity of hydrocarbon forensics when applied to chronically contaminated environments.
\end{abstract}

Keywords: Hydrocarbons contamination, Bottom sediment, Petrogenic, Biogenic, Weathering ratio (WR) and Terrigenous /aquatic ratio (TAR).

Suez Oil Petroleum Company (SOPC) industries include chemical industrial installations and oil production ${ }^{(1)}$ identified a number of hotspots where the sediments polluted by hazardous organic pollutants such as aliphatic hydrocarbons. The major sources of aliphatic hydrocarbons are oil production and other activities in the region. Chemical pollution is limited to the vicinity of industrial zones and facilities $^{(2)}$ which usually discharge their effluents: (aromatics, chemicals, fuel) which assemble $40 \%$ from local consuming: as solar, (local, banker, electrical station), benzene $(80,90,92)$, botogas, mazote by different types and characterization, sulfur (liquid and solid types), asphalt $(60,70)$ which discharged directly into the Suez Gulf in addition, free product were discharged into outlet of

*Corresponding author:dr.omaymamosa@yahoo.com 
SOPC by investigation of these products, it found (paraffin's, isoparaffins, aromatics, napthenes and olefins) and give a complete breakdown of the entire chemical component which comprise the hydrocarbons. Chemical analysis of the free product collected from the subsurface sediment reverse that several sources of petroleum hydrocarbon release are responsible for the free product plume. Mazot, Solar (diesel) and gasoline (benzene) range petroleum hydrocarbons. Sediments are deposited materials consisting of organic matter, mineral matter and inorganic material of biogenic origin. They are an efficient tool to identify environmental impacts, due to the exposure time to industrial effluents; they are valid for long term studies ${ }^{(3)}$. Sediments are considered being pollutant traps which contain a high level of pollutants ready to pass on the food chain or be mobilized by anthropogenic or natural means, so they act as indicators for the relationship between natural and anthropogenic variables. The capacity of sediment may be related to its physic-chemical properties, such as grain size and organic matter. The accumulation of hydrocarbons is more likely to occur in sediments where the water is shallow and both wave and current action is minimal ${ }^{(4)}$. Environmental pressures derive from high demographic density in the hydrographic basin of the bay in Gulf, the presence of the second major industrial complex in Gulf and the lack of suitable treatment of domestic sewage and of numerous industrial effluents. The bay provides support for activities related to petroleum exploration, transport and processing. Commercial and leisure navigation and urban runoff play a role as well in raising the levels of contamination. Because of the growing influence of fossil fuel production and uses, hydrocarbon derived contamination in the bay has become of special concern. However, for abating inputs of hydrocarbons which pose risk to animal and human health it is essential to identify the major sources to be controlled. Previous works carried out in certain areas of the bay ${ }^{(5)}$. Aliphatic and polycyclic aromatic hydrocarbons are associated with particulate and dissolved material and tend to be deposited in the sediments ${ }^{(6)}$. The composition of hydrocarbon compounds found in sediments reflects the relative contributions from different sources: biogenic, digenetic, petrogenic and pyrogenic ${ }^{(7)}$. The study of hydrocarbons in estuarine systems is immensely important as these areas are highly productive and receive large amounts of pollutants from terrestrial drainage.

Estuaries are partially enclosed water bodies with a restricted access to the sea. Due to their hydrological-geomorphologic configuration they retain, transform and accumulate a large fraction of terrestrial borne matter, with one of the material export terms being the ultimate burial in the sediments. The hydrocarbons in sediment are used for source identification and the reconstruction of the historical records of these hydrocarbon inputs for environmental impact studies. Oil pollution in sediments and natural petrogenic inputs either from oil seeps or from the erosion of ancient rocks is indicated by several features in hydrocarbon fractions. These features include the presence of the unresolved complex mixture (UCM) and a lack of predominance of an even- or odd-carbon number for $n$ alkanes ${ }^{(8)}$. Immediately, after the release of crude oil into marine waters, due to the lipophilic characteristics and bio- resistant properties of the petroleum compound, it adsorbs to the suspended particulate matter and accumulates in

Egypt. J. Chem. 57, No.2 (2014) 
bottom sediments, and it can remain unchanged and toxic for long term; thereupon, they can have a long-term effect on the structure of the benthic community $^{(9)}$. The present study investigates petroleum hydrocarbon pollution, to determine the current level of oil pollution in the sediments of SOPC discharge basin along the Suez Gulf, and also aimed to provide useful data for the environmental assessment initiatives for maritime sector for such future studies.

\section{Materials and Methods}

The reagents were all analytical reagent grade or chemically pure. All solvents were redistilled and dried before use by standard procedures ${ }^{(10,11)}$. All the oils-extracted from sediment samples were analyzed according to the standard test method IP318/75 ${ }^{(10)}$.

\section{Area of study on the Suez Gulf}

Suez Gulf to be wholly affected by the discharged pollutants (Fig. 1 and 2), outlet of Suez Oil Company is located in area about 2-3 km south west of Suez city and closed to the most important and famous international way ${ }^{(12)}$. The minimum areas and dimensions for discharge basin as a final design: Number of channel (n) is 2 , the maximum Width, $(\mathrm{B})=55 \mathrm{~m}$. Depth, $(\mathrm{d})=3.5 \mathrm{~m}$. Length, $(\mathrm{L})=148 \mathrm{~m}$. Sampling station have selected to appreciate the direct influence of associated oil activities Suez Gulf relative to a reference background level represented by the discharge basin of (SOPC).

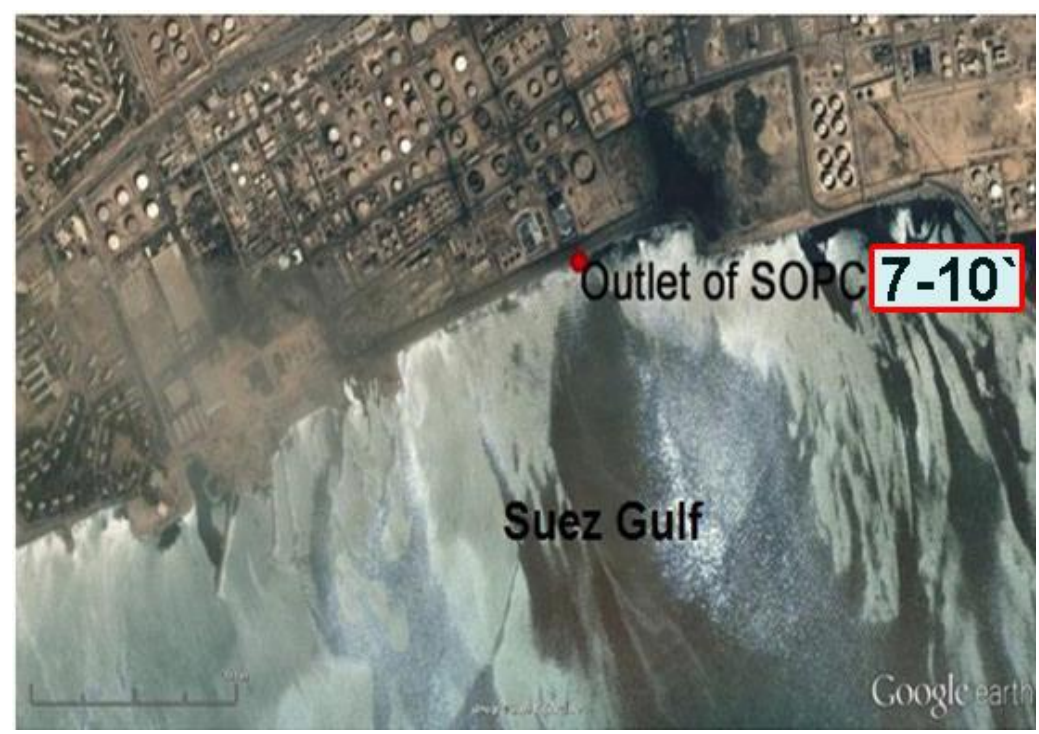

Fig. 1. Map of the discharge basin of SOPC and sampling stations along the Suez Gulf. 


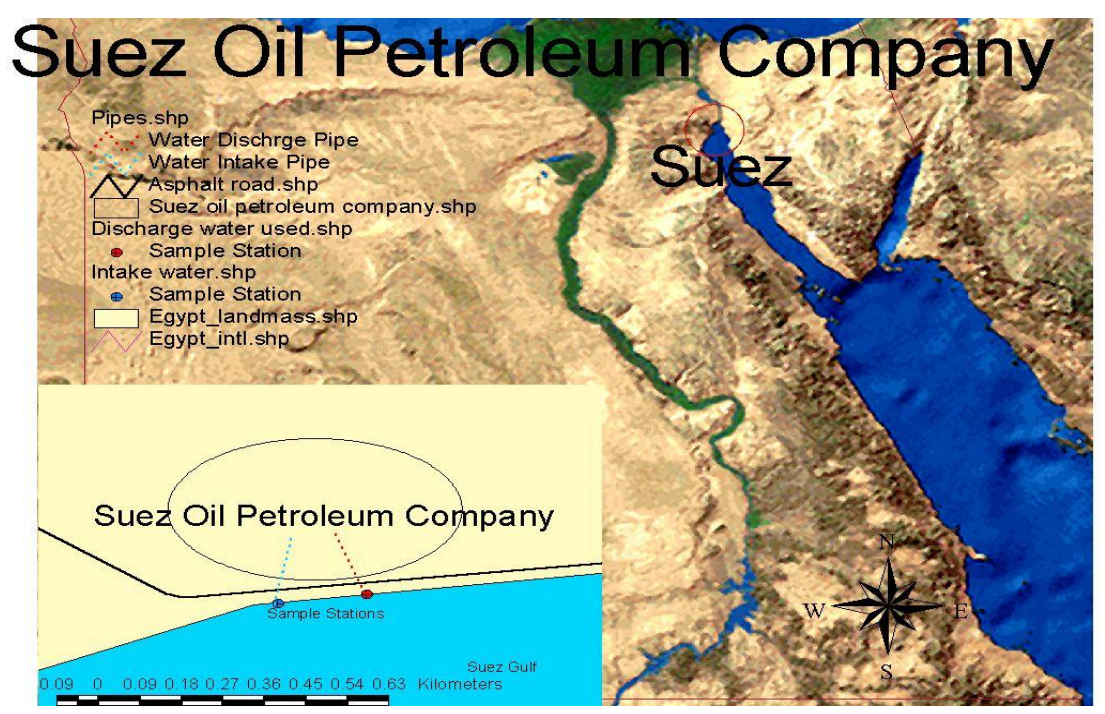

Fig. 2. Position of the Suez Oil Petroleum Company (SOPC).

Samples collection and storage

Surface sediment $(0-2 \mathrm{~cm})$ samples were collected using a stainless stell grab from different stations along the discharged Basin of (SOPC), according to activities for each site and distance (Table 1), then mixed and stored in refrigerator in pre-cleaned jars until analysis ${ }^{(13)}$.

\section{Oil extracted from sediment samples}

Sediment samples were collected from five stations at different distances along discharge basin of (SOPC). Put $500 \mathrm{~g}$. of dried, sediment in round bottomed flask $300 \mathrm{ml}$, methanol and $15 \mathrm{~g}$. potassium hydroxide were added. The mixture were refluxed for $1 \mathrm{hr}$ and $30 \mathrm{~min}$ then cooled to room temperature. The methanol extracted twice with $25 \mathrm{ml} \mathrm{n}$. hexane, then, the extract was filtered through anhydrous sodium sulphate. The volume was reduced to $0.5 \mathrm{ml}$. The reduced volume was transferred quantitively to glass vial. The extracted oil was concentrated to approximately $0.2 \mathrm{ml}$ using dry nitrogen. The oil content in sediment was then calculated after removing the solvent till constant wt. ${ }^{(14)}$.

$$
\text { The oil content was calculated as: } \mu \mathrm{g} / \mathrm{g}=\frac{(\mathrm{A}-\mathrm{B}) \times 10^{6}}{\text { Weight of gram of sample }}
$$

where: A \& B are the weight of bottle after and before action. 
TABLE 1. Studied sites, their locations, activities and distance along the drainage Basin of (SOPC).

\begin{tabular}{|c|c|c|c|}
\hline S. No. & Locations & Activities for each site & $\begin{array}{l}\text { Distance } \\
\text { along } \\
\text { drainage } \\
\text { basin (m.) }\end{array}$ \\
\hline 7 & $\begin{array}{l}\text { Outlet of Suez Oil } \\
\text { Petroleum } \\
\text { Company at } 100 \mathrm{~m} . \\
\text { /west. }\end{array}$ & $\begin{array}{l}\text { Wastes of conversion operations of crude oil } \\
\text { to refined products along the west side of the } \\
\text { outlet of petroleum drainage of Suez } \\
\text { Company with } 100 \mathrm{~m} \text {. / west. }\end{array}$ & $100 \mathrm{~m}$. / west. \\
\hline 9 & $\begin{array}{l}\text { Outlet of Suez Oil } \\
\text { Petroleum } \\
\text { Company at } 50 \mathrm{~m} \text {. } \\
\text { /west. }\end{array}$ & $\begin{array}{l}\text { Wastes of conversion operations of crude oil } \\
\text { to refined products along the west side of the } \\
\text { outlet of petroleum drainage of Suez } \\
\text { Company with } 50 \mathrm{~m} \text {. / west. }\end{array}$ & 50m. / west. \\
\hline 8 & $\begin{array}{l}\text { Outlet of Suez Oil } \\
\text { Petroleum } \\
\text { Company at }<50 \mathrm{~m} \text {. } \\
\text { /west. }\end{array}$ & $\begin{array}{l}\text { Wastes of conversion operations of crude oil } \\
\text { to refined products along the west side of the } \\
\text { outlet of petroleum drainage of Suez } \\
\text { Company with } 50 \mathrm{~m} \text {. /east. }\end{array}$ & $<50 \mathrm{~m}$./west \\
\hline 10 & $\begin{array}{l}\text { Outlet of Suez Oil } \\
\text { Petroleum } \\
\text { Company at }<50 \mathrm{~m} . \\
\text { / east. }\end{array}$ & $\begin{array}{l}\text { Wastes of conversion operations of crude oil } \\
\text { to refined products along the east side of the } \\
\text { outlet of petroleum drainage of Suez } \\
\text { Company with } 50 \mathrm{~m} \text {. least. }\end{array}$ & $<50 \mathrm{~m}$. /east \\
\hline $10^{*}$ & $\begin{array}{l}\text { Outlet of Suez Oil } \\
\text { Petroleum } \\
\text { Company at } 100 \mathrm{~m} . \\
\text { / east. }\end{array}$ & $\begin{array}{l}\text { Wastes of conversion operations of crude oil } \\
\text { to refined products along the east side of the } \\
\text { outlet of petroleum drainage of Suez } \\
\text { Company with } 100 \mathrm{~m} \text {. /east. }\end{array}$ & $100 \mathrm{~m}$. /east. \\
\hline
\end{tabular}

Gas chromatography analysis

All the oils-extracted from the studied sediment samples were analyzed using capillary column according to the standard test method IP318/75 ${ }^{(10,11)}$ for analysis and testing of petroleum and related products. Agilent 6890 plus, Gas Chromatograph with HP-5,30m0.25m mid, $0.25 \mu \mathrm{m}$ film thickness capillary column. The Carrier gas was helium at flow rate of $2 \mathrm{ml} / \mathrm{min}$. The injection volume was 0.1 $\mu \mathrm{I}$. Oven temperature increased from $80^{\circ} \mathrm{C}$ with a rate of $3{ }^{\circ} \mathrm{C} / \mathrm{min}$ up to $300{ }^{\circ} \mathrm{C}$. The injector temperature and detector temperature were $320{ }^{\circ} \mathrm{C}$.

Fourier transforms infrared spectral analysis (FT-IR)

This technique was used for the characterization of petroleum and its degradation compounds dispersed in samples. Infrared allows us to give a picture of an oil 's health and also whether any contaminants are present such as fuel or coolant. The sample as dissolved in carbon tetrachloride (A.R.) and introduced into quartz cell for analysis. Nicolet IC-10 FT-IR, Thermo Fisher Scientific model Nicolet IC-10, CS-Q 01, AKX0901119012A0607 was used in the range $4000-500 \mathrm{~cm}^{-1(15,16)}$. 
Ultraviolet analysis

Ultraviolet analysis was carried by UV/VIS/NIR Spectrophotometer (USA) V570 JASCO. The oil samples extract was dissolved in small amounts of $n$-hexane, Scanning range $200-600 \mathrm{~nm}$, the absorbance (A) was measured and their ratios were calculated as A205/ A215, A228/A256, A248/A267, A248/A278 ${ }^{(17,18)}$.

\section{Results and Discussion}

Oil contamination of surface sediment and comparable with some studied reported

Nowadays, petroleum industries are considered as one of the most important basic industries all over the world. Products derived from refining of crude oil are among the most abundant consumer products in the world. Although petroleum industries have too many benefits for our life, the pollution caused by these industries has been a cause for concern and major challenges to save the environment against their adverse impacts all over the world ${ }^{(9)}$. Immediately, after the release of crude oil into the Suez Gulf, due to the lipophilic characteristics and bio- resistant properties of the petroleum compound, it adsorbs to the suspended particulate matter and accumulates in bottom sediments, and it can remain unchanged and toxic for long term; thereupon, they can have a long-term effect on the structure of the benthic community. Due to the sensitivity of Gulf area, the studies have been performed on various pollutants and primary sources. Five samples have chosen for this study according to their locations, activities and distance taking place in each site along the drainage basin, the main activities which may cause sediment pollution as given in Table 1 and Fig. 1. Variable concentrations for oils extracted from sediment samples ranging between 1116.3 and $2137.4 \mu \mathrm{ug} / \mathrm{g}$.dry weights with average $1638.683 \mu \mathrm{g} / \mathrm{g}$. dry weights, this indicates that different hydrocarbon levels are contaminating different sites along the discharge basin according to distances. Table 2 displays the lowest values at sites (7) 1116.3 \& (10*) $1221.515 \mathrm{ug} / \mathrm{g}$ dry weights which extend (100 m.) at west and east sides, respectively along the drainage basin of (SOPC), sites (8) $2137.4 \&$ (10) $2108.666 \mathrm{ug} / \mathrm{g}$.dry weights display nearly values and higher than other due to these sites are located at $(<50 \mathrm{~m}$.) along the drainage basin from the west and east sites, respectively, beside site (9) reverse value $1609.536 \mu \mathrm{g} / \mathrm{g}$.dry weights, which located at $(50 \mathrm{~m}$.) from the west side of drainage basin. This is consistent with the direction of the water currents and winds from the west to the east sides at the basin, the high concentration for S.NO. (10*) $1221.515 \mu \mathrm{g} / \mathrm{g}$ dry weights at the east side this attributed to the presence of this site from nearby Petroleum Nasr Company. Generally, the levels of hydrocarbon in the sediment at all study areas depending on distances and sites with the west higher value than the east ones along the discharge basin therefore, the concentrations of oil content decrease with increasing the distance along drainage basin and the stations can be arranged as follows $7<10^{*}<9<10<8$ (Fig. 3). At all the petroleum concentrations as low as 0.1 ppm have been shown to be acutely toxic ${ }^{(19)}$. So, the stations, reverse concentration of oil were greatly polluted area, this due continental fraction comes mainly from some oily smuggling occurs for water and discharged via drains along the basin which is caused by refinery production units (Coking - distillation - oils), liquidation warehouses crude and petroleum products, water waste companies neighboring filter

Egypt. J. Chem. 57, No.2 (2014) 
wards pumps, Trnchat grids crude and petroleum product are assembled this oily water and pushed through a network of lines to basins separated oil during the Suez Oil Processing Company. So, the discharge basin was classified as highly polluted and aliphatic hydrocarbons concentration in sediments was categorized into four levels (guideline $\mu \mathrm{g} / \mathrm{g}$ ): Unpolluted area /natural background level (10-15), slightly polluted area / upper permissible limits (15-50), moderately polluted area (50-200), heavily polluted area ${ }^{20,9)}$. By comparing the concentration to other regions of the world (Table 3), levels are shown to be substantially higher than those from selected pristine environments. These high values may point out that high residual petroleum fractions are precipitated on sediments. These residual petroleum fractions of oil cannot be completely treated or degraded easily through weathering processing, consequently, this leads to accumulation of oil residues in sediments. The drainage basin was under stress from intensive wastes of conversion operations of crude oil to refined products along the east and west sides from it. The deliberate drainage of oil related activities and oily smuggling from the industrial processing cause continuous inputs and large cumulative loading on the discharge basin water and bottom sediments.

TABLE 2. Oil content (ug/g dry weight) extracted from drainage Basin sediment of SOPC.

\begin{tabular}{|c|c|c|}
\hline S.NO & Location & $\begin{array}{c}\text { Oil content } \\
(\mu \mathbf{g} / \mathbf{g})\end{array}$ \\
\hline 7 & Outlet of Suez Oil Petroleum Company (SOPC) at $100 \mathrm{~m}$. /West. & 11116.3 \\
\hline 9 & Outlet of Suez Oil Petroleum Company (SOPC) at 50m. /West. & 1609.536 \\
\hline 8 & Outlet of Suez Oil Petroleum Company (SOPC) at $<50 \mathrm{~m} . /$ west. & 2137.4 \\
\hline 10 & Outlet of Suez Oil Petroleum Company (SOPC) at $<50 \mathrm{~m}$. /east. & 2108.666 \\
\hline $10^{*}$ & Outlet of Suez Oil Petroleum Company (SOPC) at $100 \mathrm{~m}$. /east. & 1221.515 \\
\hline
\end{tabular}

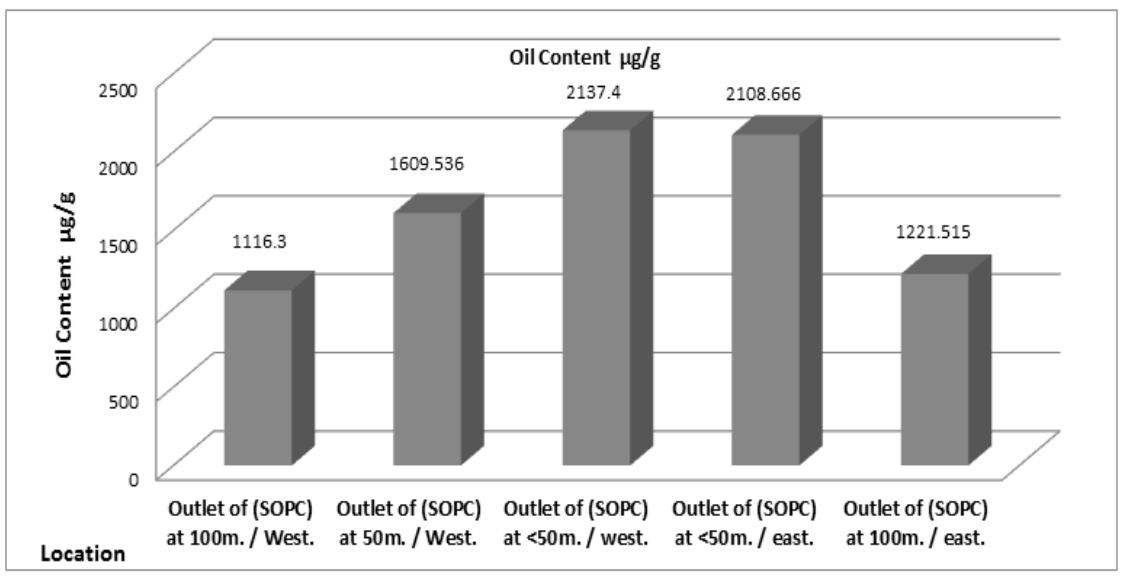

Fig. 3. Histogram representing oil content concentration $(\mu \mathrm{g} / \mathrm{g}$ dry weight) extracted from drainage Basin of SOPC. 
TABLE 3. Comparison between levels of petroleum hydrocarbons in sediments $(\mu \mathrm{g} / \mathrm{g})$ from different regions of the marine environments.

\begin{tabular}{|c|c|c|c|c|c|}
\hline Area & Site & $\begin{array}{l}\text { Range } \\
(\mu \mathrm{g} / \mathrm{g})\end{array}$ & Mean & Guideline $^{(9)}$ & References \\
\hline Suez Canal & Suez Canal & $2.91-127.7$ & 32.37 & $10-15$ & (21) \\
\hline Suez Canal & Suez Canal & $0.04-2.45$ & 32.37 & $10-15$ & (22) \\
\hline Red Sea & $\begin{array}{l}\text { Saudi Arabia } \\
\text { Coast }\end{array}$ & $10.3-803$ & 326.9 & $10-15$ & (23) \\
\hline Mediterranean Sea & Damietta Harbor & $0.16-4.16$ & 1.44 & $10-15$ & (24) \\
\hline Black Sea & Monaco & $2.1-310$ & 59.656 & $10-15$ & (13) \\
\hline Mediterranean Sea & \begin{tabular}{|l} 
Damietta - \\
Port Said \\
\end{tabular} & $15.50-100.2$ & 48.8 & $10-15$ & (11) \\
\hline Mediterranean Sea & $\begin{array}{l}\text { Damietta - } \\
\text { Man zalah lake }\end{array}$ & $121.5-579.9$ & 260.632 & $10-15$ & (15). \\
\hline Mediterranean Sea & Alexandria, Egypt & $\begin{array}{c}14.3-170.4 \text { summer) } \\
12.1-107.9 \text { (winter) }\end{array}$ & $\begin{array}{l}55.342 \\
27.145\end{array}$ & $10-15$ & (25). \\
\hline North Africa, Spain & Ceuta harbor: & $496-6972$ & $\begin{array}{c}3331 \pm \\
2317\end{array}$ & $10-15$ & (26). \\
\hline Candarli Gulf & Turkey & $3.88-24.7$ & 8.695 & $10-15$ & (27). \\
\hline Musa Bay, & $\begin{array}{l}\text { Northwest of the } \\
\text { Persian Gulf- Iran }\end{array}$ & $17.51-88.81$ & 45.94 & $10-15$ & (9). \\
\hline Mediterranean Sea & $\begin{array}{l}\text { EL- Man zalah } \\
\text { lake }\end{array}$ & $5.0-132.5$ & -------- & $10-15$ & (28) \\
\hline Suez Gulf & $\begin{array}{l}\text { Discharge Basin } \\
\text { of (SOPC) }\end{array}$ & $1116.3-2137.4$ & 1638.683 & $10-15$ & This work \\
\hline
\end{tabular}

Gas chromatographic analysis $(G C)$

Gas Chromatographic Analysis (GC) for oil extracted from sediments is achieved for severely weathered oils and refined products not only $n$-alkanes but also branched and cyclo-alkanes are heavily or completely lost and the UCM becomes extremely pronounced, resulting in significant increase in relative ratios of UCM/GC- TPH, and in a substantial decrease in relative ratios of resolved peaks to GC- TPH ${ }^{(29)}$. The studied sediment samples gave chromatogram similar to those for petroleum weathered profiles consisting of a number of $n$ - alkenes peaks starting from $n \mathrm{C}_{11}$ up to $n \mathrm{C}_{36}$ for the samples (Fig. 4 and Table 4). Also, the chromatograms profile is characterized by the presence of relatively large UCM hump with small peaks shows the different degrees of weathering effect in all samples, and the absence of low molecular weight hydrocarbons in most samples. It is clear that all samples are contaminated by petrogenic origin hydrocarbons (regularly spaced small peaks over well defined UCM) are shown in Biogenic sources for hydrocarbons indicated by the dominance of $n$-alkanes $\left(n \mathrm{C}_{17}, n \mathrm{C}_{19}, n \mathrm{C}_{25} \text {, and } n \mathrm{C}_{29}\right)^{(28,30)}$, which are synthesized by marine algae and higher terrestrial plant waxes. The paraffinic hydrocarbons are shown to decrease regularly to different extents indicating various degrees of weathering.

Egypt. J. Chem. 57, No.2 (2014) 


\section{$G C$ - parameters}

Carbon preference index (CPI)

An unresolved complex mixture (UCM) occurring in the range $n \mathrm{C}_{18}-n \mathrm{C}_{35}$ is an indicator of petroleum contamination ${ }^{(31)}$. In order to determine the natural or anthropogenic origin of the $n$-alkanes, the carbon preference index (CPI) was calculated as the sum of the odd carbon numbered alkanes to the sum of the even carbon numbered alkanes, CPI indexes were determined for each sample set (Table 4). CPI indicated the relative contributions from natural sources (biogenic/terrestrial; CPI $>1$ ) and anthropogenic sources (petroleum pollution and highly degraded of organic matter, $\mathrm{CPI} \approx 1$ ) at station (8). Each sample has CPI values maximized is as higher plant inputs drastically increased through rain drains ${ }^{(32)}$. CPI data of sediment samples ranged from 0.071 to 0.974 , but the assumption cannot be accepted by discussing the profiles of the chromatograms obtained which are shown to be typically petrogenic. On the other hand, petroleum oils are characterized by CPI values around $(1.00)^{(18,33)}$, the presence of high concentration of $n$-paraffin $\left(n \mathrm{C}_{25}\right.$ or $\left.n \mathrm{C}_{23}\right)$ causes this confusion gave an indication of the biogenic origin ${ }^{(16)}$. The CPI values were calculated again without taking in consideration the value of $n \mathrm{C}_{25}$ or $n \mathrm{C}_{23}$ peak areas. Table 4 , shows the results for the CPI correct values ranged from 0.046 to 0.872 . These indicate that the petrogenic origin is mainly predominating, while little biogenic contaminations can be detected especially that of $n \mathrm{C}_{25}$.

\section{Unresolved / resolved complex mixture ratio}

$\mathrm{UCM}$ or hump of un-resolved hydrocarbons is one of the more convincing indication of the petrogenic origin and the extent of weathering and biodegradation $(30,34)$.The ratio of un-resolved to resolved components $U / R$ has been calculated for most samples usually $\mathrm{U} / \mathrm{R}>4$ is used as a criterion for the presence of important petroleum residue ${ }^{(35,36)}$. Table 4 for sediment samples show values between 2.757 to 16.765 due to high concentrations of aromatic and naphthenic compounds. The high values of the UCM in sediment samples, as with those obtained in the present study, have been reported as evidence of chronic oil-pollution.

\section{n- Alkanes quantization results}

The aliphatic hydrocarbon distribution consisted of resolved compounds (mostly $n$-alkanes) and an unresolved complex mixture $(\mathrm{UCM})^{(16)}$. The distributions of $n$-alkanes are shown in Fig. 4. An UCM, consisting of branched and cyclic hydrocarbons, was present in all samples. The UCM indicated that more pronounced petroleum-related inputs occurred at the distances of sampling sites along discharge basin; industrial complex of the petroleum Suez Company and different activities' processing appeared then to be the major sources of such inputs in the study area. Careful examination of Table 4 and Fig. 4 illustrates that total alkanes percentage concentration of pollutants from samples sites 8, 10, $10 * \& 9$ ranges from 5.629 to $9.087 \%$ whereas, aromatic and cyclic compounds percentages ranges from 90.913 to $94.371 \%$ including a significant hump representing large amounts of UCM from naphthenic and aromatic compound. Further, the presence of UCM in the aliphatic fraction is considered as the most important indicator of petrogenic pollution by weathered or degraded petroleum residues, when the maximum height occurs mainly in the higher molecular weight. Yet, it has also been linked to bacterial degradation of natural organic inputs algal detritus ${ }^{(37)}$. 
Weathering ratio $(W R)$

Evaporations and dissolution effects are detected by calculating both (WR) $\Sigma n \mathrm{C}_{23}-\mathrm{C}_{34} / \Sigma n \mathrm{C}_{11}-n \mathrm{C}_{22}$ and $\left\langle n \mathrm{C}_{17} /\right.$ total alkane ${ }^{(16)}$. From Table $4,<n \mathrm{C}_{17} /$ total alkanes range between 0.041 to 0.562 , also (WR) have variable values showing different degrees of weathering ranged from 0.098 up to 0.468 . These variations indicate various industrial complex of the Petroleum Suez Company as a result of activities processing and discharged of the different pollutants to the Company discharge basin.

\section{$n C_{14}-n C_{18}$ five isoprenoid}

This ratio of $n$-alkanes / iso-alkanes is defined as the ratio of the sum of $n \mathrm{C}_{14^{-}}$ $n \mathrm{C}_{18}$ over the sum of farnesane, trimethylC $\mathrm{C}_{13}$, norpristane, pristane and phytane ${ }^{(35)}$. Data obtained in Table 4 , show that this ratio varies from 0.330 up to 91.742 for surface sediment samples. Low value observed for S.NO.10 (0.330) while, S.NO.7 \&10* display relatively high values $9.174 \& 2.733$, respectively due to being less weathered compared with other samples. Also, sample 8 (0.641) exhibits low value due to extensive weathering, indicating the same degree of weathering due to photo-oxidation, vaporization and biodegradation processes along the discharge basin.

Tn. alkanes/Tiso-alkanes

Normal alkanes are usually degraded more rapidly than the isoprenoid alkanes ${ }^{(38)}$.So this ratio is used as an index for the degree of weathering (mainly biodegradation). This ratio decreases with increasing weathering. Table 4 shows the following sequence: $7<10^{*}<8<10<9$, for weathering effects. The relatively higher differences between sequences are due to the differences in the added biogenic hydrocarbons specially that of $\mathrm{nC}_{25}$.

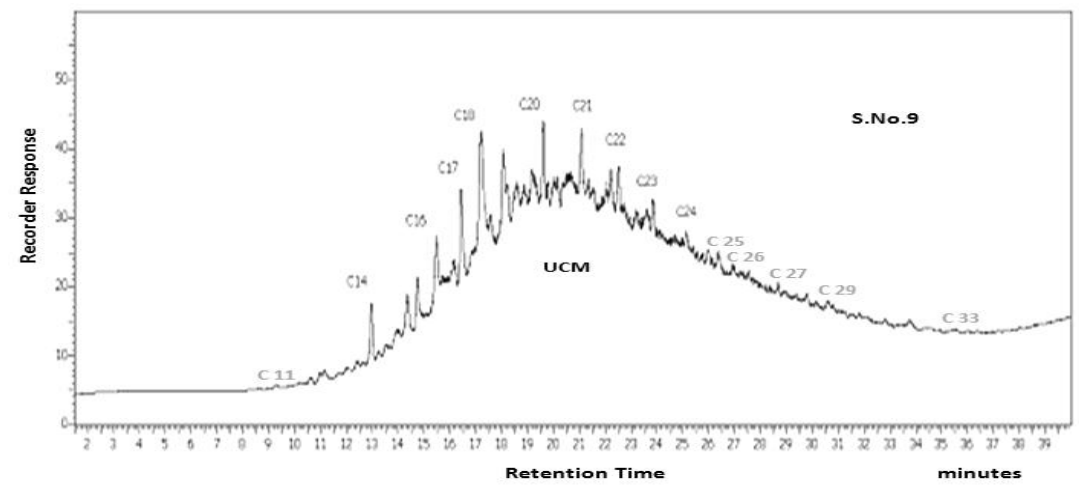

Fig. 4. GC chromatogram of extracted oil of sample no. 9 as an example of GC analysis. 


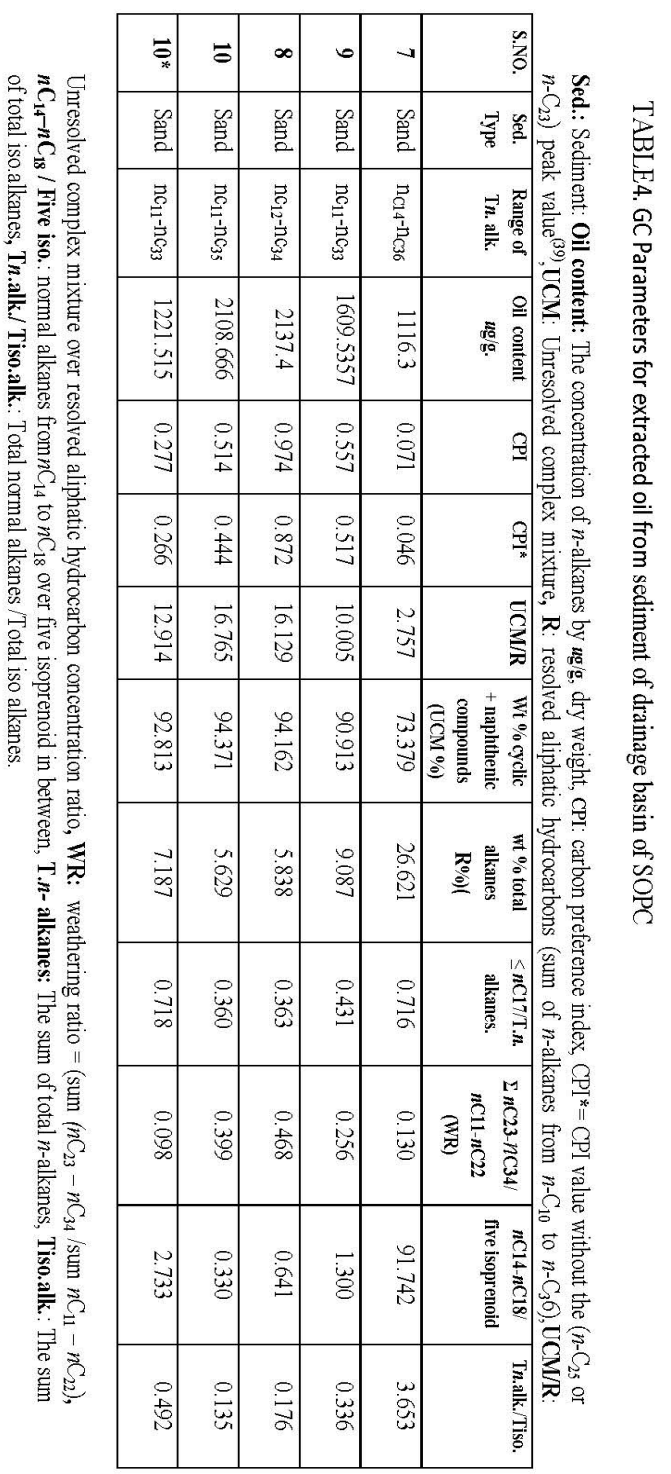

Egypt. J. Chem. 57, No.2 (2014) 
The ratios of (LMW) low molecular weight to $(H M W)$ high molecular weight

A total of 26 aliphatic hydrocarbons $\left(n \mathrm{C}_{11}-n \mathrm{C}_{36}\right)$ were measured for all sediment samples. The concentrations of total aliphatic hydrocarbons ranged from 11.930 to $78.510 \mathrm{ng} / \mathrm{g}$ (dry weight) Table 5 and exhibited large variation among stations. Highest concentrations occurred at the station 7 and lowest one was found in S.NO.10. It appears that for all stations except stations 10*, the concentrations of $n \mathrm{C}_{10}$ to $n \mathrm{C}_{20}$ hydrocarbons were more concentrated than the longer chain (>20) $n$-alkanes. The ratios of low molecular weight (LMW, sum of $n \mathrm{C}_{10}$ to $n \mathrm{C}_{20}$ ) to high molecular weight (HMW, sum of $n \mathrm{C}_{21}$ to $n \mathrm{C}_{34}$ ) LMW/ HMW $n$-alkanes are indicated in Table 5.It has been reported that LMW/ HMW ratios that are less than unity (1) usually represent $n$-alkanes produced by higher plants, marine animals and sedimentary bacteria, while LMW/HMW ratios close or greater than unity suggest $n$-alkanes that are mainly from petroleum and plankton sources ${ }^{(40,41)}$. As summarized in Table 5, the LMW/HMW ratios are all greater than unity for most samples, except station $10^{*}$, indicating the presence of $n$-alkanes in the sediments is mainly from petroleum-originated contaminations. Aliphatic hydrocarbons diagnostic ratios were studied in order to identify contamination sources. According to the scientific literature many ratios of selected molecular species can be used.

The Pr/Ph, $n C 17 / P r$ and $n C_{18} / \mathrm{Ph}$ ratios

In this study the $\mathrm{Pr} / \mathrm{Ph}, n \mathrm{C}_{17 /} \mathrm{Pr}$ and $n \mathrm{C}_{18} / \mathrm{Ph}$ ratios were adopted and calculated (Table 5), the $n \mathrm{C}_{17} / \mathrm{Pr}$ ratios, in the range of $0.136-2.295, n \mathrm{C} 18 / \mathrm{Ph}$ $0.050-2.630$ and $\mathrm{Pr} / \mathrm{Ph} 0.207-2.025$. Overall, the $n \mathrm{C}_{17} / \mathrm{Pr}, n \mathrm{C}_{18} / \mathrm{Ph}$ and $\mathrm{Pr} / \mathrm{Ph}$ values are higher than 1 for all sediment samples. These results show a possible petrogenic origin for hydrocarbons in effluents ${ }^{(42,43)}$.

\section{Terrestrial hydrocarbons}

The study of hydrocarbons based on the analysis of biogeochemical markers as well as the different tracers of origin permits to distinguish two main origins: biogenic and anthropogenic. The important presence of the $n \mathrm{C}_{15}, n \mathrm{C}_{17}$, and $n \mathrm{C}_{19}$ is strongly assigned to a marine biogenic origin relative to the phytoplankton ${ }^{(18)}$. Terrestrial hydrocarbons are characterized by elevated concentrations in compounds that have high molecular weights and odd carbon numbers, such as $n \mathrm{C}_{31}, n \mathrm{C}_{33}$, and $n \mathrm{C}_{35}$. The distribution of odd/even carbon numbers for petroleum-related pollution, however, is relatively even (Table 5). The ratio of terrigenous-to-aquatic $n$-alkanes were estimated as terrigenous /aquatic ratio $(\mathrm{TAR})=\left(n \mathrm{C}_{27}+n \mathrm{C}_{29}+n \mathrm{C}_{31}\right) /\left(n \mathrm{C}_{15}+n \mathrm{C}_{17}+n \mathrm{C}_{19}\right)^{(44.45,27)}$. This ratio is valuable for determining changes in relative contributions of organic matter from land and aquatic flora although it may over-represent the absolute amounts from terrigenous sources. This ratio was adopted in the present study to estimate the relative contribution of terrigenous and processing refiner's sources to the sediments. Station 7 showed comparatively high TAR value 1.595 among the five sediment samples along the drainage Basin of SOPC, which could be caused by input of sediment with high TAR values from the high proportions of relict sediments. The relict sediments presumably have high TAR ratios based on the fact that aquatic $n$-alkanes degrade faster than terrigenous $n$-alkanes.

Egypt. J. Chem. 57, No.2 (2014) 
TABLE 5. Aliphatic hydrocarbon concentrations (ug/g, dry weight) in sediment of the discharge basin of SOPC.

\begin{tabular}{|c|c|c|c|c|c|}
\hline $\begin{array}{l}\text { Aliphatic } \\
\text { hydrocarbons }\end{array}$ & 7 & 9 & 8 & 10 & $10 *$ \\
\hline $\mathrm{nC}_{11}$ & N.D. & 0.090 & N.D. & 0.060 & 0.230 \\
\hline $\mathrm{nC}_{12}$ & N.D. & 0.080 & 0.050 & 0.140 & 0.020 \\
\hline $\mathrm{nC}_{13}$ & N.D. & 0.080 & 0.030 & 0.290 & 0.050 \\
\hline $\mathrm{nC}_{14}$ & 55.94 & 4.350 & 2.240 & 3.150 & 19.830 \\
\hline $\mathrm{nC}_{15}$ & 0.050 & 0.470 & 0.460 & 0.170 & 1.350 \\
\hline $\mathrm{nC}_{16}$ & 0.160 & 2.530 & 1.840 & 0.270 & 0.810 \\
\hline $\mathrm{nC}_{17}$ & 0.080 & 1.070 & 0.110 & 0.210 & 1.400 \\
\hline Pristane & 0.070 & 0.550 & 0.810 & 0.100 & 0.610 \\
\hline $\mathrm{nC}_{18}$ & 4.320 & 3.060 & 0.020 & 0.710 & 1.080 \\
\hline Phytane & N.D. & 2.660 & 0.400 & 0.270 & 1.010 \\
\hline $\mathrm{nC}_{19}$ & 0.980 & 3.790 & 3.520 & 0.970 & 2.300 \\
\hline $\mathrm{nC}_{20}$ & 4.720 & 1.300 & 0.490 & 1.150 & 0.900 \\
\hline $\mathrm{nC}_{21}$ & 0.290 & 1.360 & 0.080 & 0.240 & 0.070 \\
\hline $\mathrm{nC}_{22}$ & 2.660 & 2.080 & 0.240 & 1.160 & 1.280 \\
\hline $\mathrm{nC}_{23}$ & 0.340 & 0.190 & 0.660 & 0.750 & 0.450 \\
\hline $\mathrm{nC}_{24}$ & 2.53 & 1.070 & 0.920 & 0.690 & 0.310 \\
\hline $\mathrm{nC}_{25}$ & 1.810 & 0.960 & 0.770 & 0.550 & 0.470 \\
\hline $\mathrm{nC}_{26}$ & 0.520 & 0.740 & 0.580 & 0.400 & 0.780 \\
\hline $\mathrm{nC}_{27}$ & 0.810 & 0.030 & 0.310 & 0.380 & 0.120 \\
\hline $\mathrm{nC}_{28}$ & 0.780 & 0.480 & 0.400 & 0.060 & 0.620 \\
\hline $\mathrm{nC}_{29}$ & 0.600 & 0.570 & 0.450 & 0.130 & 0.420 \\
\hline $\mathrm{nC}_{30}$ & 0.410 & 0.310 & 0.230 & 0.010 & 0.130 \\
\hline $\mathrm{nC}_{31}$ & 0.360 & 0.160 & 0.250 & 0.120 & 0.280 \\
\hline $\mathrm{nC}_{32}$ & 0.390 & 0.120 & 0.090 & 0.130 & 0.080 \\
\hline $\mathrm{nC}_{33}$ & 0.180 & 0.550 & 0.03 & 0.170 & 0.010 \\
\hline $\mathrm{nC}_{34}$ & 0.260 & N.D. & 0.09 & 0.010 & N.D. \\
\hline $\mathrm{nC}_{35}$ & 0.200 & N.D. & N.D. & 0.010 & N.D. \\
\hline $\mathrm{nC}_{36}$ & 0.120 & N.D. & N.D. & N.D. & N.D. \\
\hline $\mathrm{nC}_{17} / \mathrm{Pr}$ & 1.143 & 1.945 & 0.136 & 2.100 & 2.295 \\
\hline $\mathrm{nC}_{18} / \mathrm{Ph}$ & N.D. & 1.150 & 0.050 & 2.630 & 1.069 \\
\hline $\mathrm{Pr} / \mathrm{Ph}$ & N.D. & 0.207 & 2.025 & 0.370 & 0.604 \\
\hline TAR & 1.595 & 0.143 & 0.211 & 0.467 & 0.162 \\
\hline LMW & 66.25 & 13.030 & 9.84 & 7.120 & 27.970 \\
\hline HMW & 11.94 & 12.390 & 5.100 & 4.800 & 32.990 \\
\hline LMW/HMW & 5.549 & 1.052 & 1.292 & 1.483 & 0.848 \\
\hline Total Aliphatic & 78.510 & 25.420 & 14.940 & 11.930 & 32.99 \\
\hline
\end{tabular}

T. $n$-ALK: total resolved $n$-alkanes fromnC $\mathrm{C}_{11}$ to $\mathrm{nC}_{36}$ with two isoprenoids, pristane and phytane. (pr): Isoprenoids(pr): pritane and (ph); phytane, $n \mathrm{C}_{17} / \mathrm{Pr}$.: normal alkanes of $n \mathrm{C}_{17}$ over pristane, $n \mathrm{C}_{18} / \mathrm{Ph}$.: normal alkanes of $n \mathrm{C}_{18}$ over phytane, $\mathrm{Pr} / \mathrm{Ph}$ : pristane $(\mathrm{Pr})$ over phytane $(\mathrm{Ph})$ ratio; TAR: terrigenous/aquatic ratio = $\left(n \mathrm{C}_{27}+n \mathrm{C}_{29}+n \mathrm{C}_{31}\right) /\left(n \mathrm{C}_{15}+n \mathrm{C}_{17}+n \mathrm{C}_{19}\right)$; LMW/HMW: the ratios of low molecular weight (LMW, sum of $n-\mathrm{C}_{10}$ to $n-\mathrm{C}_{20}$ ) to high molecular weight (HMW, sum of $n-\mathrm{C}_{21}$ to $\left.n-\mathrm{C}_{34}\right){ }^{(39)}$, N.D.: Under the limit of detection. 
UV spectral analysis

The UV Spectrophotometer (USA) technique, V-570 JASCO modeling, and hydrocarbon composition were used to characterize oil components and to examine the oil extracted from sediment under controlled laboratory conditions (Fig. 5). The spectra for the studied samples show significant bands at 205, 215, 248, 256, 267 and $268 \mathrm{~nm}$. This denotes that different aromatic classes are present in the extracted oils ${ }^{(46)}$. The recommended four major absorption ratios were identified, at 205/215,228/256, 248/267, and 248/278 nm, respectively (Table 6). An average was determined for the oil components based on UV Spectrophotometer and hydrocarbon composition measurements, the first ratio $205 / 215^{(11)}$ pointed generally higher values relative to the other three ratios $228 / 256,248 / 267$, and $248 / 278 \mathrm{~nm}$, ranging between 0.8986 up to $1.0299 \mathrm{ug} / \mathrm{g}$. This indicates high concentrations of mono-aromatic hydrocarbons, compounds such as benzene, toluene and xylene that may be not lost during weathering process, due to continuous inputs of freshly particular oil. Good matching between the studied samples in this range, indicating that low molecular weight aromatics have nearly identical values. The second ratio $228 / 256^{(47)}$, is constant for oil and independent on oil concentration, displayed values between 0.8440 and $0.9228 \mathrm{ug} / \mathrm{g}$ which reveal different sources of oils polluted these areas. The third ratio $248 / 267$ has values varying between 0.8187 up to 0.8892 with averaging $0.8659 \mathrm{ug} / \mathrm{g}$. This ratio is significant for di-aromatic hydrocarbons. The last ratio $248 / 278$ ranging from 0.6350 to $0.7240 \mathrm{ug} / \mathrm{g}$ averaging $0.6879 \mathrm{ug} / \mathrm{g}$ indicating the presence of different types of poly-aromatics, these compounds are described as the most carcinogenic components, which have great toxic and harmful effects.

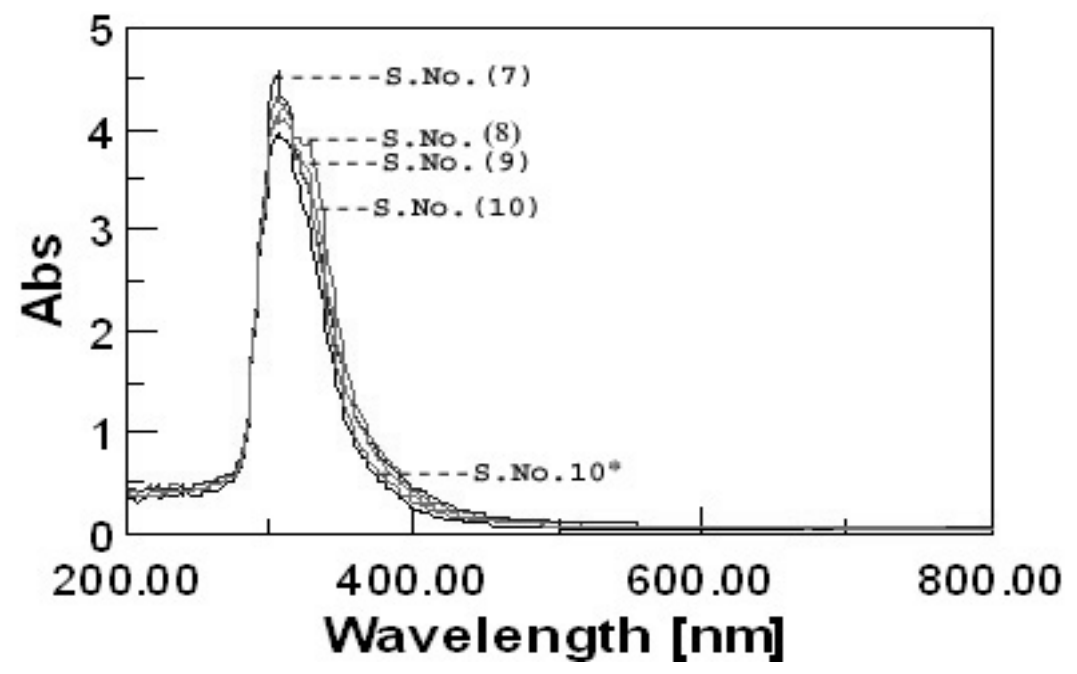

Fig. 5. UV absorption spectra for oils extracted from sediment of drainage Suez Company.

Egypt. J. Chem. 57, No.2 (2014) 
TABLE 6. Calculated UV absorption ratios for oils extracted from sediment of drainage Basin of SOPC.

\begin{tabular}{|c|c|c|c|c|c|}
\hline S.NO. & Location & $\begin{array}{c}\mathbf{A 2 0 5} / \\
\mathbf{A 2 1 5}\end{array}$ & $\begin{array}{c}\mathbf{A 2 2 8} / \\
\mathbf{A 2 6 5}\end{array}$ & $\begin{array}{c}\mathbf{A 2 4 8} \text { A267 } \\
\mathbf{A 2 4 8 /}\end{array}$ & $\begin{array}{c}\mathbf{A 2 7 8} \\
\mathbf{A 2 7 8}\end{array}$ \\
\hline 7 & $\begin{array}{c}\text { Outlet of Suez Oil } \\
\text { Petroleum Company at } \\
\text { 100m. /West. }\end{array}$ & 1.0299 & 0.8440 & 0.8718 & 0.6879 \\
\hline 8 & $\begin{array}{c}\text { Outlet of Suez Oil } \\
\text { Petroleum Company at } \\
\text { 50m. /West. }\end{array}$ & 0.8986 & 0.8893 & 0.8892 & 0.7240 \\
\hline 9 & $\begin{array}{c}\text { Outlet of Suez Oil } \\
\text { Petroleum Company at } \\
<50 \mathrm{~m} . / \text { west. }\end{array}$ & 1.0137 & 0.8902 & 0.8676 & 0.6955 \\
\hline 10 & $\begin{array}{c}\text { Outlet of Suez Oil } \\
\text { Petroleum Company at } \\
\text { <50m. /east. }\end{array}$ & 1.0578 & 0.9118 & 0.8821 & 0.6972 \\
\hline $10 *$ & $\begin{array}{c}\text { Outlet of Suez Oil } \\
\text { Petroleum Company at } \\
100 \mathrm{~m} . / \text { /east. }\end{array}$ & 0.9614 & 0.9228 & 0.8187 & 0.6350 \\
\hline
\end{tabular}

A: Absorbance.

FT- IR spectral analysis

1. The IR spectra for the oils extracted from sediment samples are presented in Table 7 and Fig. 6. The characteristic bands for aliphatic hydrocarbons appear as a strong bands at 2923 and $2859 \mathrm{~cm}^{-1}$ due to stretching vibration of methylene groups $\left(\right.$ Vas $\left.\mathrm{CH}_{2}\right)$ and $\left(\mathrm{Vs} \mathrm{CH}_{2}\right)$ stretching vibration, respectively ${ }^{(48)}$.

2. Strong bands at $1456 \mathrm{~cm}^{-1}$ due to $\left(\right.$ as $\left.\mathrm{CH}_{3}\right)$ bending vibration of $\mathrm{CH}_{3}$ group from aliphatic hydrocarbons, and medium band at $1375 \mathrm{~cm}^{-1}$ due to $\left(\mathrm{SsCH}_{3}\right)$ bending of $\mathrm{CH}_{3}$ group $^{(38)}$.

3. Medium band appear at $753 \mathrm{~cm}^{-1}$ due to out of plane bending of $=\mathrm{C}-\mathrm{H}$ group in mono and poly-nuclear aromatic ${ }^{(49,18)}$. Indeed, an intense band in the region of $1700 \mathrm{~cm}^{-1}$ was observed for the naphthenic acidic fractions, indicating that there was an increasing concentration of acid species ${ }^{(50)}$.

4. Finally, a medium band at $813 \mathrm{~cm}^{-1}$ was significant for naphthenic aromatic compounds, $(\mathrm{CH}$ aromatic out of - plane deformation, 2 or 3 adjacent free hydrogen atoms $)^{(51)}$.

TABLE 7. Infra red signals and assignments of the oil extracted from the surface sediment.

\begin{tabular}{|c|l|}
\hline $\begin{array}{c}\text { Wave } \\
\text { number } \mathbf{c m}^{-1}\end{array}$ & \multicolumn{1}{c|}{ Assignments of chemical groups } \\
\hline 2923 & A stretching vibration of methylene groups $\left(\mathrm{Vas} \mathrm{CH}_{2}\right)$ \\
\hline 2859 & A stretching vibration of methylene groups $\left(\mathrm{Vs}_{3} \mathrm{CH}_{3}\right)$ \\
\hline 1462 & $\delta$ as $\mathrm{CH}_{3}$ bending stretching of vibration of $\mathrm{CH}_{3}$ group \\
\hline 1375 & $\delta$ s $\mathrm{CH}_{3}$ bending stretching of vibration of $\mathrm{CH}_{3}$ group \\
\hline 735 & out of plane bending of =C-H group in mono and poly-nuclear aromatics \\
\hline 810 & significant for naphthenic aromatic compounds \\
\hline 1700 & $\mathrm{C}=\mathrm{O}$ stretching in carbonyl group \\
\hline
\end{tabular}

Egypt. J. Chem. 57, No.2 (2014) 


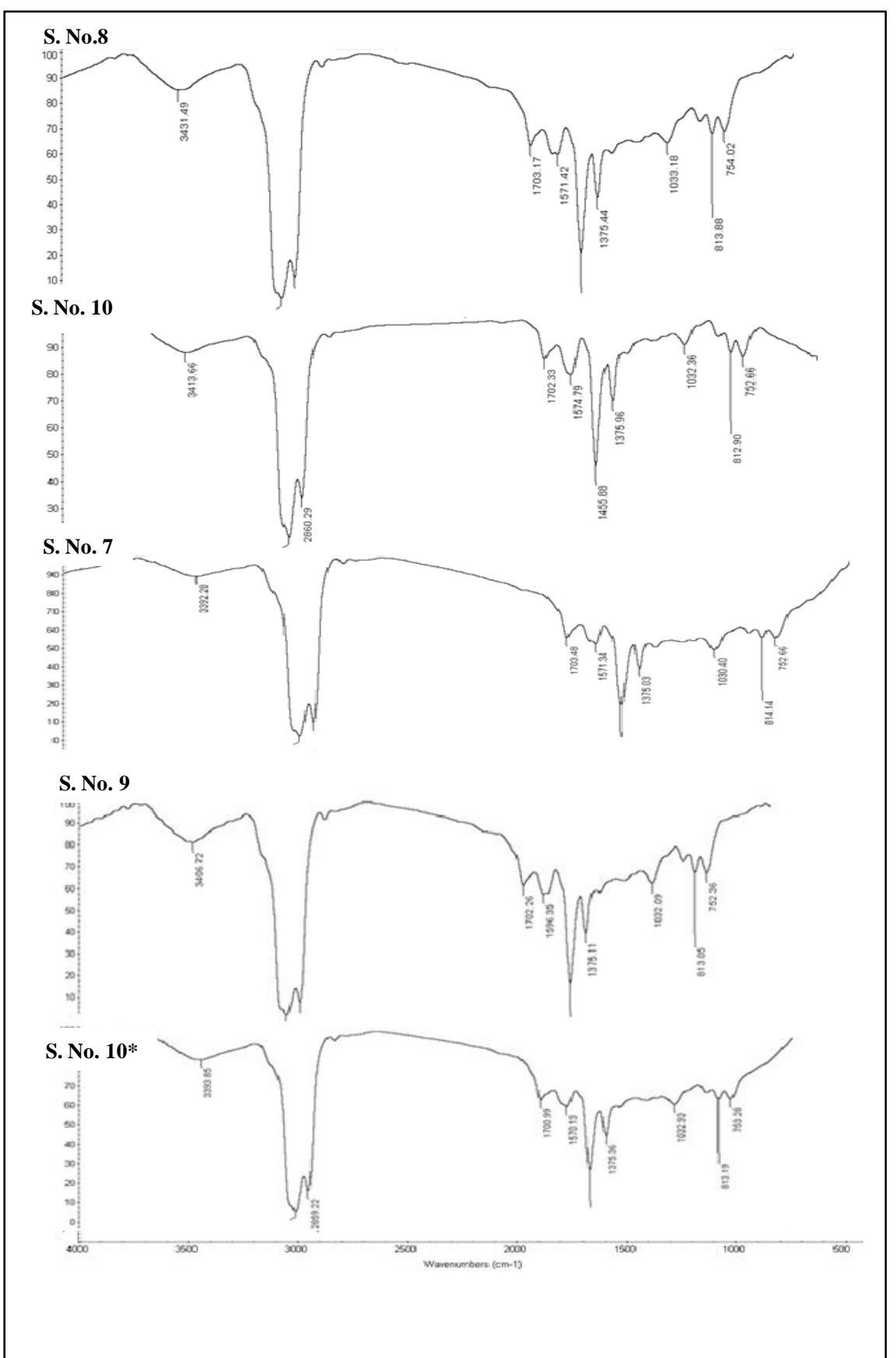

Fig. 6. FT-IR absorption spectra for oils extracted from sediment of drainage Basin of SOPC.

Egypt. J. Chem. 57, No.2 (2014) 


\section{Conclusion and Recommendations}

1. In the present work, we attempt to present for the first time the distribution and the origin of hydrocarbons in sediments from discharge basin in the Petroleum Suez Company. The $n$-alkanes in the same location have multiple sources: anthropogenic / petrogenic and traces of biogenic hydrocarbons.

2. Total hydrocarbon concentrations were relatively high compared to other coastal sediments and ranged from 1116.3 up to $2137.4 \mathrm{ug} / \mathrm{g}$.dry weights with average $1638.6834 \mathrm{ug} / \mathrm{g}$.dry weights.

3. A complexes mixture of aliphatic hydrocarbons evidences that the concentration was greater than the natural background concentration; therefore, the discharge basin can be considered (highly) polluted, this is due to the deliberate drainage of oil related activities and oily smuggling from the industrial processing which cause continuous inputs and large cumulative loading on the discharge basin water and bottom sediments, without completely treated or degraded easily through weathering processing.

4. Despite the high concentration of anthropogenic contaminates including industries, processing activities and other non-point source pollution. The present work demonstrates the complexity of hydrocarbon forensics when applied to chronically contaminated environments.

5. The high values of the UCM due to high concentrations of aromatic and naphthenic compounds have been reported as evidence of chronic oilpollution.

6. CPI values indicate that the petrogenic origin is mainly predominating, while little biogenic contaminations can be detected especially from $n \mathrm{C}_{25}$. This could indicate a potential of biodegradation which is not encountered in the more polluted stations.

7. Hydrocarbons were deposited on surface sediments from a variety of processing sources: an industrial effluent in the discharge basin as a result of oily smuggling occurs with water.

8. Hydrocarbon distribution is an important and useful tool in organic geochemistry studies. UV analysis for oils incorporated in sediments reveals that oil pollutants have considerable amounts of aromatic compounds.

9. FT-IR spectroscopic analysis indicates high concentrations of aliphatic hydrocarbons as well as mono and poly-nuclear aromatic hydrocarbons in addition to naphthenic compounds.

10.The discharge of hazardous materials such as petroleum and chemical solvents to the aquatic environment has become the focus of increasing regulatory and public concern because of the adverse impacts of such materials on human health and the environment; petroleum concentrations as low as $0.1 \mathrm{ppm}$ have been shown to be acutely toxic .

11. Commitment to Environmental Law for the year 1994 on the protection of water and beaches, and which is required to address the wastes within companies before being discharged to the drainage basins, and control in preventing the diversion of oily water by separating oils and which are subject to the standards of permissible concentrations globally. 


\section{References}

1. Povelsen E., Alshabrawy M. M., Mohammed A.S. and El-Seoud A.A., Heavy Metals and Hazardous Organic Pollutants in Sediment and Mussels in the Gulf of Suez, 1999 and 2001, Egyptian Environmental Affairs Agency (2003).

2. PERSGA, Strategic Action Programme for the Red Sea and Gulf of Aden, Regional Organization for the Conservation of the Environment of the Red Sea and Gulf of Aden (1998).

3. Mostafa Y.M. and El-Naggar A.Y., Distribution and of poly-aromatics hydrocarbons in sediment of sues canal. The $6^{\text {th }}$ International Conferences on Petroleum Mineral Resources and Development, Egyptian Petroleum Research Institute (Epri), (2003).

4. Nagla M.K., PhD. Thesis entitled, Studied on Pollutants Contaminating Red Sea Marine Environmental with Special Emphasis to Aromatic Hydrocarbons (Al-Azhar University), (Girls Branch) (2006).

5. Angela de L.R. W., Maria de F., G.G. Meniconi , C. Hamacher I., C.O. Farias, Gilson C.D.S., Irene T.G. and Arthur de L.S., Hydrocarbons in sediments of a chronically contaminated bay: The challenge of source assignment. Marine Pollution Bulletin, 64, 284-29 (2012).

6. Peng, X., Wang, Z., Yu, Y., Tang, C., Lu, H., Xu, S., Chen, F., Mai, B., Chen, S. and $\mathbf{L i}, \mathbf{K}$. and Yang, C., Temporal trends of hydrocarbons in sediment cores from the Pearl River Estuary and the northern South China Sea. Environ. Pollut. 156 , $442-448$ (2008).

7. Hu, L., Guo, Z., Shi, X., Qin, Y., Lei, K. and Zhang, G., Temporal trends of aliphatic and polyaromatic hydrocarbons in the Bohai Sea, China: Evidence from the sedimentary record. Org. Geochem. 42, 1181-1193 (2011).

8. Thais, R.S., Silvia, R.P. L., Gertrud, S., Bastiaan, A.K. and Débora, A.A., Evaluation of anthropogenic inputs of hydrocarbons in sediment cores from a tropical Brazilian estuarine system . Micro Chemical Journal, 109, 178-188 (2013).

9. Ghazaleh, M.T., Rosli, H., Abdul, H.S., Seyedeh, B.T., Sany, R.K.J. and Zhamak, M.T., Assessment of contamination by petroleum hydrocarbons in sediments of Musa Bay, Northwest of the Persian Gulf-Iran, International Conference on Environment. Energy and Biotechnology, 33 (2012).

10. IP Standards, for analysis and testing of petroleum and related products, Institute of Petroleum, London, V1 (1993).

11. Abd El Rahman, M. Mousa, Nazik, A. Farid, Mageed, M. Soliman and Omayma E. Ahmed, Identification of the hydrocarbons in coastal sediments from the Mediterranean Damietta - Port Said Sea Shore. Egypt. J. Petrol. 10 (1) , (2000).

12. REMIP WORKING GROUPs 2 (WG2), JICA and EEAA, State oil pollution and Management in Suez Gulf region, page 15 (2008).

13. Readman, J.W., Fillmann, G., Tolosa, I., Bartocci, J., Villeneuve, J. P.,Catinni, C. and Mee L.D., Petroleum and PAH contamination of the Black Sea. Marine Pollution Bulletin, 44, 48-62 (2002).

Egypt. J. Chem. 57, No.2 (2014) 
14. Viguri, J., Verde, J. and Iranien, A., Environmental assessment of polycyclic hydrocarbons (PAHS) surface sediments of the Santander Bay ' Northern Spain. Chemosphere, 48, 157- 165( 2002).

15. Maged, M. Soliman, Omyma, E. Ahmed, Nazik, A. Farid and Abd El Rahman, M. Mousa, Parameters related to pollution by petroleum in Manzalah Lake bottom sediments. Egypt. J. Amal. Chem. 8, 56-69 (1999).

16. Nazik, A. Farid, Mohamed Ibrahim, Omayma E. Ahmed, Rabie Saad Mostafa and Emara, M., State of petroleum pollution in the Suez Gulf coastal waters, "The $17^{\text {th }}$ International Conference on Petroleum Mineral Resources and Development, Feb., 9 - 11 (2014).

17. Ehrhardt, M. and Petrick, G., Relative concentrations of dissolved/dispersed fossil fuel residues in Mediterranean surface waters as measured by UV fluorescence. Marine Pollution Bulletin, 20, 560-565 (1989).

18. Omayma E. Ahmed, Nabila A. Ali, Sawsan A. Mahmoud and Mamdouh M. Doheim , Environmental assessment of contamination by petroleum hydrocarbons in the aquatic species of Suez Gulf, ISSN: 2166-074 Florida, USA. International Journal of Modern Organic Chemistry, 3(1), 1-17 (2014).

19. USEPA Quality Criteria for Water, US Environmental Protection Agency, Office of Water Regulations: Standard, Washington, DC, EPA, 440/5-86-001 (1986).

20. Massoud, M. S., Al-Abdalib, A. F., Al - Ghadbanb, A. N. and Al-Sarawia, M. , Bottom sediments of the Arabian Gulf-II, TPH and TOC Contents as Indicators of Oil Pollution and Implications for The Effect and Fate of The Kuwait Oil Slick, ELSEVIER (1996).

21. El-Agroudy Nadia, Abdallah and Abd El-Ghany, Environmental Studies on Hydrocarbon Materials in Suez Canal Provide (2001).

22. El-Samra, M.I., El Deeb, K.Z., Askar, A.I.,Wahby, S.D. and El Shazly, M.S.H., Preliminary study of petroleum hydrocarbon pollution along the Suez Canal. Bull. Nat. Inst. Oceanography \& Fish, 9, 97 - 101 (1983).

23. Ehrhardt, M.G. and Burns, K.A., Hydrocarbons and related photo oxidation products in Saudi Arabian Gulf coastal waters and hydrocarbons in underlying sediments and bio-indicator bivalves. Marine Pollution Bulletin, 27, 187-197 (1993).

24. Shereet, S.M., Pollution of petroleum hydrocarbon in the new Damietta harbor. Egypt. Emirates Journal for Engineering Research, 14 (1), 65-71 (2009).

25. Omayma E. Ahmed, Ph.D. Thesis entitled "Pollution of water and shores of Alexandria with ship wastes of simple and polymeric chemicals and their treatment. Faculty of Science Institute of Environmental Studies and Research , Ain Shams University, p.163 (2005).

26. Guerra, J.M.F.J., García, J.C., González, V. and Garcia, G., Aliphatic hydrocarbon pollution and macro benthic assemblages in Ceuta harbor: a multivariate approach. Mar. Ecol. Prog. Ser. Published November 28, 263, 127-138 (2003). 
27. Filiz, K., Idil, P. and L. Tolga, G., Marine organic pollutants of the Eastern Aegean: Aliphatic and polycyclic aromatic hydrocarbons in Candarli Gulf sacrificial sediments.Marine Pollution Bulletin, 64, 2569-2575 (2012).

28. Roushdy, M. I., Brakat, M. and Eman, Ouf, Impacts of Petroleum Pollutants on EImanzala Lake. Egyptian Petroleum Research Institute Nasr City, Cairo, Egypt, The $15^{\text {th }}$ International Conference on Petroleum. Mineral Resources and Development. 810- April, Cairo, Egypt (2012).

29. KrumhoIzi, R., Caldwell, M.E., Suflita, J. M., Crawfold, R. L. Craw and Ford, D. L., Hydrocarbons under Anaerobic Conditions, In Bioremediation: Principles and Applications."Cambridge University Press, UK. pp., 61-99 (1996).

30. Saida, B., Soumayak, Ioanna, B., Alain, S. and Hassan, Er. R., Assessment of the Moroccan Mediterranean Coasts contamination by hydrocarbon (non aromatic hydrocarbons, aromatic hydrocarbons and linear alkyl benzenes), International Journal of Geosciences, 2, 562-572 (2011).

31. Ebirien, P.F., Bassey, O.E., Okon, D. E. and Hab, L.M., Predominance's and source implications of even $n$-alkenes in surface sediments from coastal areas of Niger Delta, Nigeria. International Journal of Basic \& Applied Sciences, 12 (02) , 68 (2012).

32. Jalila, A., Claude, G. R., Fehmi B.O., Ezzeddine, M., Patricia, A., Mohamed, K. and André, A., Organic matter compounds as source indicators and tracers for pollution in a western Mediterranean coastal zone. Sci. Pollut., Res DOI, 10.1007/s11356-011-0522 (2011).

33. Medeiros, P.M. and Bicego, M.C., Investigation of natural and anthropogenic hydrocarbon inputs in sediments using geo chemical markers. Marine Pollution Bulletin, 49, 461 - 769 (2004).

34. Tolosa, I., Mora, S., Sheikh, Oieslami, M., Villeneuve, J., bar tocci, J. and AbdCattini, C., Aliphatic and aromatic hydrocarbons in coastal Caspian Sea sediments. Marine Pollution Bulletin, 48 (1-2), 44-60 ( 2004).

35. Eman, M.K.A., Thesis submitted for MSc. Physico-Chemical Studies on Some Selected Water Pollutants, Al-Azhar University (2013).

36. Gogou, A., Bouloubassi, I. and Stephanou, E.G., Marine organic geochemistry of the Eastern Mediterranean: I. Aliphatic and polyaromatic hydrocarbons in Cretan Sea sacrificial sediments. Mar Chem., 68, 265-282 (2000).

37. Mohamed, I. A., Thesis submitted for MSc. Studied on water quality in selected area of Egypt, AL-Azhar University (2012).

38. Abd-El- Rahman, M., Mousa, Nazik, A. Farid, Maged, M., Soliman and Omayma E., Ahmed, Contamination of water on Alexandria seashore, $15^{\text {th }}$ International Conference on Petroleum Mineral Resources and Development 8-10 April, Cairo, Egypt (2012).

39. Catherine, G., Marc, T., Sébastien, G. and Madeleine, G., Occurrence and distribution of hydrocarbons in the surface micro layer and subsurface water from the urban coastal marine area off Marseilles, Northwestern Mediterranean Sea. Marine Pollution Bulletin, 62, 2741-2752 (2011).

Egypt. J. Chem. 57, No.2 (2014) 
40. Gearing, P., Gearing, J., Lytle, T.F. and Lytle, J., Hydrocarbons in 60 northeast Gulf of Mexico shelf sediments: a preliminary survey. Geochemist Cosmo him. Ac., 40, 1005-1017 (1976).

41. Riccardia, C., Filippoa, P.D., Pomataa, D., Incoronatoa, F., Basilioa, M.D., Papinib, M.P. and Spicagliaa, S., Characterization and distribution of petroleum hydrocarbons and heavy metals in groundwater from three Italian tanks farms. Sci. Total Environ. 393, 50-63 (2008).

42. Tran, K., Yu, C.C. and Zeng, E.Y., Organic pollutants in the coastal environment off San Diego, California.2, Petrogenic and biogenic sources of aliphatic hydrocarbons. Environ. Toxicol. Chem. 16, 189-195 (1997).

43.Gokdeniz, N.E., Aynur, K., Deniz, U., Oya, A., Enis, D., Esin, U., Filiz, K., Nermin, T.U. and Funda, Y., Polycyclic aromatic and aliphatic hydrocarbons pollution at the coast of Aliaga (Turkey) ship recycling zone. Marine Pollution Bulletin, 64, 1055-1059 (2012).

44. Meyers, P. A., Organic geochemical proxies of pale Oceanographic Paleolimnologic and pale climatic processes. Org. Geochem. 27, 213-250 (1997).

45. Chen, M.P., Lin, K.L. and Huang, C.K., Sedimentary structure and texture of sacrificial sediment off northeastern Taiwan. Ti-Chih (ROC) 15, 15-47 (1995).

46. Neveka, A., Bionda, K.S. and Rak, N., International. J. Environmental Analytical Chemistry, 39, 381 (1990).

47. Zhengzhen, Z., Zhanfei, L. and Laodong, G., Chemical evolutions of Macon do crude oil during laboratory degradation as characterized by fluorescence EEMs and hydrocarbon composition. Marine Pollution Bulletin, 66, 164-175 (2013).

48. Sayed, S.A. and Zayed, A.M.A., Study on using some local clay in treatment of liquid oil spill, $1{ }^{\text {st }}$ Int .Conf. on New Trends in Chemistry and their Applications Cairo, unit, Benin-Suez, Egypt. Feb.2-4 (2004).

49. Narve, A., Harald, K. and Johan, S., Determination of saturate, aromatic, resin and asphaltenic (SARA) Components in Crude Oils by means of infrared and near infrared spectroscopy the Norwegian University of Science and Technology, Department of Chemical Engineering , 15 (5), pp. 1304-1312 (2001).

50. Keroly, A.P., Colati, Guilherme, P., Dalmaschio Eustquio, V.R., de Castro, Alexandre, O., Gomesb Boniek, G. and Vaz Wanderson Rom, Monitoring the liquid / liquid extraction of naphthenic acids in Brazilian crude oil using electro spray ionization FT-ICR mass spectrometry (ESI FT-ICR MS) . Fuel, 108, 647-655 (2013).

51. Yanan Xing, MSc. Thesis entitled, Characterizations of dissolved organic carbon in prairie surface waters using Fourier transform infrared spectroscopy, University of Saskatchewan Saskatoon (2010). 


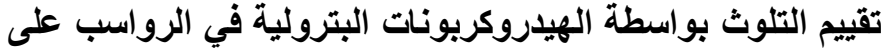

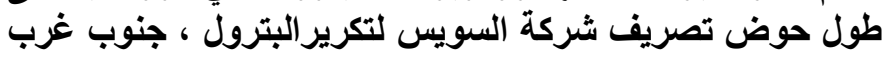

$$
\begin{aligned}
& \text { خليج السويس توض تصنيا } \\
& \text { معهد بحوث البترول - مدينة نصر - معرى القاهرة - مصر. }
\end{aligned}
$$

شركة النفط بالسويس هى أول شركة وطنية لتكرير البترول في مصر ، منذ عام

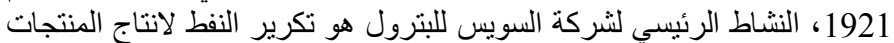

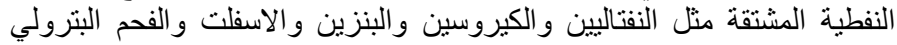

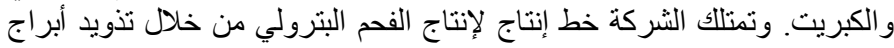

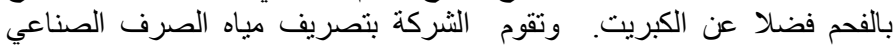

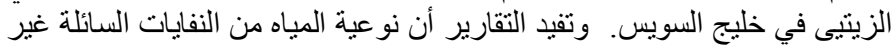

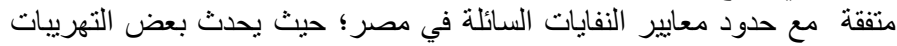

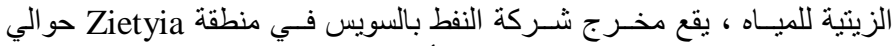

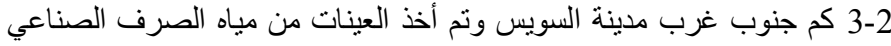

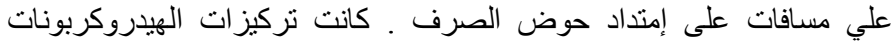

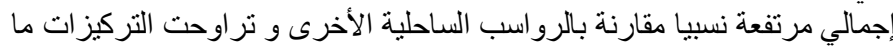

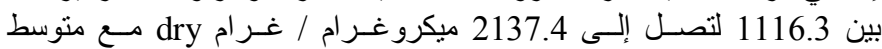

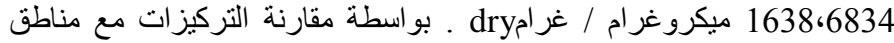

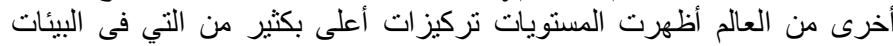

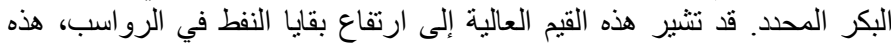

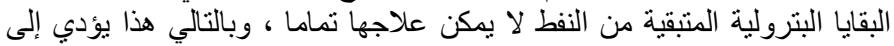

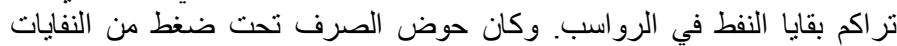

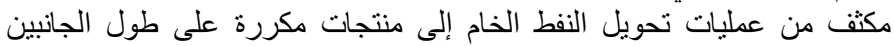

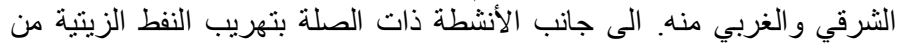

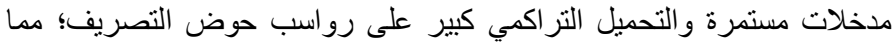

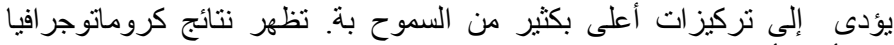

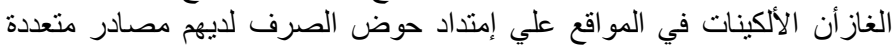
petrogenic Biogenic ،petrogenic

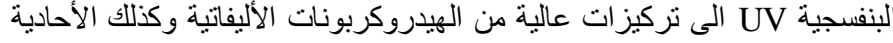

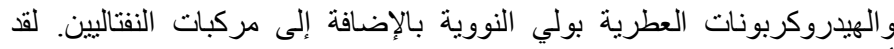

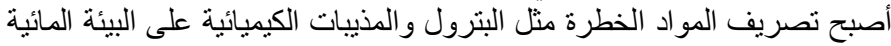

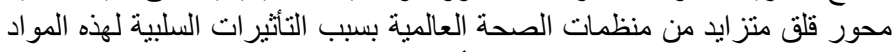

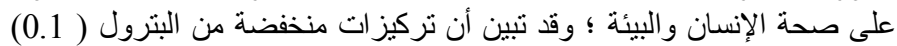

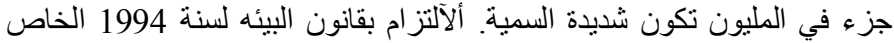

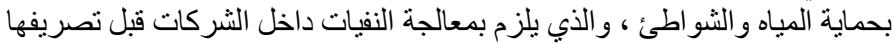

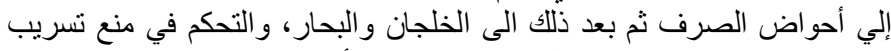

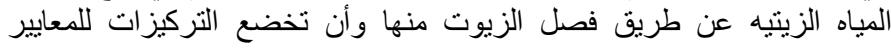
المسموح بها عالميا. 